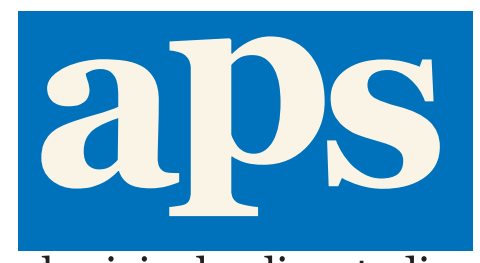

aboriginal policy studies

\title{
Article
}

\section{What Now? Future Federal Responsibilities Towards Aboriginal People Living in Cities}

\author{
Frances Abele and Katherine Graham
}

aboriginal policy studies, Vol. 1, no. 1, 2011, pp. 162-182

This article can be found at:

http://ejournals.library.ualberta.ca/index.php/aps/1/1/AbeleGraham.pdf

ISSN: 1923-3299

aboriginal policy studies is an online, peer-reviewed and multidisciplinary journal that publishes original, scholarly, and policy-relevant research on issues relevant to Métis, non-status Indians and urban Aboriginal people in Canada. For more information, please contact us at apsjournal@ualberta.ca or visit our website at

www.ualberta.ca/NATIVESTUDIES/aps/

or

http://ejournals.library.ualberta.ca/index.php/aps/ 


\title{
What Now? Future Federal Responsibilities Towards Aboriginal People Living in Cities
}

\author{
Frances Abele and Katherine Graham \\ Carleton University
}

\begin{abstract}
For decades, successive federal governments insisted that the federal fiduciary responsibility to "Registered Indians" ended at reserve boundaries, while not recognizing any responsibilities for Non-Status Indians, Métis, and Inuit. The recent growth of urban Aboriginal populations has changed this situation dramatically. Many federal programs for urban Aboriginal people are now delivered in a "status-blind" fashion, while other services are still entangled in or complicated by the provisions of the Indian Act. This paper explores the policy history underlying the current situation while identifying four issues for further discussion: (1) political self-determination in the cities; (2) problems arising from the cities' junior position in the Canadian federation; (3) the challenge of dealing with the diversity of circumstances and preferences of Aboriginal and nonAboriginal urban dwellers; and (4) the legacy of differential programs based upon differentiations among sections of the Aboriginal population that no longer have constitutional salience. Long-term solutions, such as replacing the Indian Act, creating a "cities charter" and creating addenda to treaties or section 35 are discussed.
\end{abstract}

For decades, successive federal governments insisted that the federal fiduciary responsibility to "Registered Indians" ended at reserve boundaries, while responsibilities to other Aboriginal people-Non-Status Indians, Métis, and Inuit-were not recognized at all. Over the last several decades, both of these policy positions have been gradually and somewhat unevenly eroded. The situation today differs substantially from the recent past, and it carries its own tensions and contradictions. ${ }^{1}$ Many federal programs for Aboriginal people are now delivered in cities and in a "status-blind" fashion, while

aboriginal policy studies, Vol. 1, no. 1, 2011

ISSN: 1923-3299

www.ualberta.ca/NATIVESTUDIES/aps/ 
other services are still entangled in the provisions of the Indian Act and the accumulated policies and practices that are in line with it. Furthermore, the situation in the cities has grown more complex. While cities have borne the brunt of two decades of fiscal restraint and economic restructuring, they have also been the site of increasingly intense debates about immigration and its impacts on cities and city governments. The implications of these potentially overlapping and colliding imperatives on the capacity of all levels of government to adequately address their responsibilities towards Aboriginal people living in cities have yet to be fully explored.

The main drivers of change in matters of direct concern to Aboriginal people living in cities have been demographic and political. While only a small minority of Aboriginal people lived in cities fifty years ago, over half do today, including more than 20 percent of Inuit. At the same time, the political organization and activism of Aboriginal people has brought changes to jurisprudence, to the constitution, and to resulting federal policy and programs. In this paper, we sketch some of the historical roots of these changes and consider their implications for factors that now shape federal responsibilities to Aboriginal people in the cities. Because the changes made over the last fifty years have been both profound and incremental, we suggest that it is time for a review of the role played by the federal government in ensuring consistent treatment for Aboriginal people in cities and easing the stresses of current inconsistencies on service providers and on urban Aboriginal people. We argue that such a review needs to acknowledge the strong interplay amongst the recognition of Aboriginal rights, approaches to delivering services for Aboriginal people in cities, and improving public awareness and understanding of Canada's fundamental relationship with Aboriginal peoples in the context of our changing urban demographics. There is a need for strong federal leadership in dealing with each of these three dimensions and with the relationships among them. We conclude by asking a few open questions, in the hope of stimulating further research and discussion. $^{2}$

\section{Starting Points}

From the beginning, colonial and then Dominion government policy marked off a segment of the Aboriginal population as Registered Indians. ${ }^{3}$ These individuals were those persons listed in colonial and then federal records, usually after they signed a treaty with the Crown. Registered Indians were 
thereby subject to the Indian Act and, by virtue of this position, assigned to the federal order of government for certain health and social services that are provided at the provincial level for the rest of the Canadian population. In a situation that is unusual in Canadian history, Registered Indians were also subject to a direct form of rule by the executive branch (Abele 2007). From the time before Confederation until at least the end of World War II, the federal Indian administration assumed that Registered Indians required both protection and control. Registered Indians were expected to make their lives on reserves, where many aspects of their lives were subject to control and social engineering, until they were ready to assume full citizenship and live among the general population. ${ }^{4}$

In contrast, First Nations members who were not on the Indian Register were understood to be "Non-Status Indians." However, they may have ended up in this category, ${ }^{5}$ federal policy regarded them as undifferentiated from other Canadian citizens. Most importantly, as a result, Non-Status Indians did not have access to reserves: that is, to the collectively held lands such as those set aside for Registered Indians. In most parts of the country, the same was true for Métis or mixed heritage peoples, although the Red River Métis fought for the right to self-govern on collectively held lands in two nineteenth-century rebellions or "Resistances." Inuit, who until recently lived almost entirely in Arctic Canada (Labrador, Quebec, and the pre-1991 Northwest Territories), had no experience of the Indian Act or of reserves, most moving to small communities in the north in the first two decades after the Second World War.

At the onset of World War II, there were few Aboriginal people living in Canadian cities. Some reserves were close enough to urban centres to make contact feasible, but the strictures of Indian Act administration inhibited interaction between reserve residents and their neighbours. Most Aboriginal people were living in rural areas, either on reserves or on their traditional territories (considered in policy to be Crown land) and making their living from available local opportunities, many based in the harvesting econony. They were visitors to towns and cities, not residents. All of this began to change after World War II, when changes to the Indian Act, the experience of wartime service, and the introduction of a new approach to social welfare provision all made migration to the cities a more viable prospect for Aboriginal people as well as other rural Canadians. ${ }^{7}$ In early days, the federal government's policy construction of this phenomenon was rooted in social engineering. As early as 1958, the Citizenship and 
Indian Affairs Branch initiated a program of support and tutelage for Status Indians and their families to move to cities for employment and betterment. Candidates were carefully chosen. The classification "urban Aboriginal" began to emerge in federal parlance in the early 1960s (Peters 2001). Finally, the landmark Hawthorn Report, released in 1966, focused on Status Indians living on reserve but argued that migration, especially from remote reserves, would be necessary for economic wellbeing (Government of Canada 1966).

As we have argued elsewhere, ${ }^{8}$ the federal engagement in municipal and in Aboriginal affairs has ebbed and flowed in response to developments in the greater Canadian political economy and in Aboriginal-state relations. Municipal matters, constitutionally a matter for provincial governments, drew federal attention in the 1960s and 1970s, at the same time as Aboriginal activism was beginning to bring about changes in the law and in federal programming. ${ }^{9}$ This period saw the first federal programs for cities, the first funding for (city-based) Aboriginal organizations, and the first initiatives responding to Aboriginal people living in the cities. By the end of the1970s, however, the attention of policy-makers and the media had shifted away from local, community, and city affairs during the debates and political struggles that attended the 1982 patriation of the Canadian Constitution. Aboriginal politics, too, reflected this preoccupation with ensuring entrenchment of appropriate recognition of collective Aboriginal rights. The period after patriation was marked by deteriorating relations between leading Aboriginal organizations and the federal government, culminating in the failure of the last constitutionally mandated First Minister's Conference on Aboriginal Rights (1987) to either advance the Aboriginal agenda or put in place alternative modes of policy discussion (Abele and Graham 1988). A period of Aboriginal protest ensued (see Peach 2004; Ladner and Simpson 2010). In the absence of adequate fora for their resolution, conflicts over land rights became political confrontations. The most prominent example from this period is probably the conflict over Mohawk lands at Kanesatake, near Oka, Quebec. This conflict, which escalated into an armed standoff, spread to another Mohawk territory, Kanewake, which borders the city of Montreal. A bridge blockade and other actions resulted in direct conflict between the Mohawks and their Montreal neighbours. ${ }^{10}$

In 1991, in the aftermath of the armed standoff at Kanesetake and gathering protests across the country, the federal cabinet established the Royal Commission on Aboriginal Peoples (RCAP). ${ }^{11}$ The sixteen-part mandate of the commission was prepared by retired Supreme Court Chief 
Justice Brian Dickson, after extensive consultation. Dickson charged RCAP with considering a large agenda of outstanding issues in Aboriginal-Canada relations. It included, however, almost no specific mention of urban issues. In this respect, the RCAP mandate was a good indication of prevailing preoccupations at the beginning of the 1990s: treaties, land rights, the implications of the new provisions in the Constitution Act of 1982, Métis and Non-Status rights, and economic development. Item 9 of the mandate, "Special issues of concern to aboriginal peoples," contains the only direct mention of urban issues: $:^{12}$

In particular, the Commission may study and make concrete recommendations to improve the quality of life for aboriginal peoples living on reserve, in native settlements and communities, and in rural areas and cities. Issues of concern include, but are not limited to: poverty, unemployment and underemployment, access to health care and health concerns generally, alcohol and substance abuse, sub-standard housing, high suicide rates, child care, child welfare, and family violence (RCAP 1:701; emphasis added).

It is noteworthy that this set of residual issues was cast in terms of socio-economic and service concerns, rather than being seen through the prism of rights.

Chief Justice Dickson could not know that the terms of social provision in just these areas were about to shift dramatically. While the Commission deliberated (1992-1996), large changes were underway in Canadian public policy. The election of 1993 brought the Liberals to power, and both Prime Minister Jean Chrétien and Minister of Finance Paul Martin became convinced that it was necessary to make reduction of the federal deficit a priority. A program review carried out during 1994-1995 was to profoundly change the pattern of federal spending in all areas of social provision. At the core of the program review was a restructuring of federal expenditures in many other areas, essentially exporting programs and responsibilities to other orders of government or to non-governmental organizations. These measures were accompanied by significant fiscal restraint. The Canada Health and Social Transfer (CHST) replaced the longstanding cost-shared programs through which the federal government had contributed to funding health, education, and social assistance. 
The Royal Commission's 1996 final report included extensive treatments of social and economic issues that were linked analytically to the Commission's major themes of recognition and reconciliation, and to the affirmation of Aboriginal rights. The five-volume report contains a single chapter on urban issues, which was based upon a limited research base and a well-attended and public round table on urban issues. It emphasized specific models of governance that the Commission deemed viable for urban Aboriginal people and service delivery in cities, matters that do not receive much attention elsewhere in the report.

RCAP's treatment of urban issues is significant. In one sense, it was very much a product of its time, coming at the end of a period in which urban Aboriginal matters could be treated as secondary. ${ }^{13}$ It is also a reflection of the Commissioners' preoccupation with the interaction of core issues related to Aboriginal-Crown relations, namely land, treaty rights and the specific basis and quality of the relationship. Nonetheless, the Commission's analysis of the potential for new models of urban governance and new roles and relationships involving Aboriginal people in urban areas was groundbreaking. It marks the beginning of public discussion of the interplay among recognition of Aboriginal rights, servicing issues, and awareness in cities. RCAP's analysis and recommendations also point to the role of the federal government (as well as others) in this regard.

The 1990s public sector restructuring and restraint measures had a major impact on Canadian cities. As federal and provincial governments withdrew funding from programs that affected the social and economic fabric of the cities (e.g., by reducing funding for social housing and social assistance for single people), hardships increased for city governments and for the poorer people living in Canadian cities. Homelessness emerged as a significant public issue in all Canadian cities. In each province and territory, the downloading of social programs increased financial pressures on city governments and led, as well, to the development of numerous small nongovernmental organizations for the provision of services. This massive change occurred at the same time as the economic base of Canadian cities began to change, as the effects of the Canada-US and the North American Free Trade Agreements were felt. ${ }^{14}$

In Aboriginal affairs, the changes of the early 1990s brought opportunities as well as hardships. The cutbacks and restraints of this period affected Aboriginal people, as they did all other Canadians. On the other hand, a new model of federal funding of Aboriginal social programs 
emerged, bringing with it greater opportunities for Aboriginal control of Aboriginal services (Abele 2004). ${ }^{15}$ Under the new model, numerous small, Aboriginal-controlled service organizations were established, many of them in urban centres, including organizations with a primary focus on capacity building and others that focused primarily on direct service provision. These included the Indigenous Leadership Development Institute (ILDI), based in Winnipeg; many healthcare providers, such as the Vancouver Native Health Society and Poundmakers Lodge in Edmonton; educational programs, like the Saskatchewan Urban Native Teacher Education Program in Regina and Saskatoon, and the Joe Duquette High School in Edmonton; and economic and employment development organizations like the Estey School Aboriginal Employment Program in Saskatoon, Anishinaabe OwayIshi (Aboriginal youth employment preparation and placement program) in Winnipeg (Newhouse 2003, 248-49). ${ }^{16}$ Organizations with longer histories also benefited from the availability of project funding, and an Aboriginal "third sector" began to be consolidated, constituting established lines of operation, a network of contacts, and a cohort of experienced staff.

While the Royal Commission deliberated, important changes to federal Aboriginal policy were announced. In 1995, the federal Cabinet recognized the inherent right of self-government for the Aboriginal peoples of Canada - Indian, Inuit, and Métis people - pursuant to sSection 35 of the Constitution Act (1982). Released jointly by the Minister of Indian Affairs and Northern Development and the Federal Interlocutor for Métis and NonStatus Indians, the inherent right policy explicitly recognized the right of self-government of "Métis and Indian Groups Off a Land Base" (Canada 1995; Wherret 1999). To date, there has not been a similar effort to develop policy concerning self-government for Aboriginal people living in Canadian cities. ${ }^{17}$

Nevertheless, the official federal response to the RCAP report, released in 1998 (Canada 1998), offered a new approach to policy development in Aboriginal affairs. This approach emphasized the concept of "partnership" and made room for a degree of shared decision makingwithin established parameters, of course. Consultative policy councils and committees blossomed in such areas of service provision as labour force development, programs for children, and health promotion initiatives. Although the new policy councils and committees were introduced for programs that affected Aboriginal people wherever they lived, participants have tended to be urban-dwelling organizational staff and the programs 
generally have a strong presence in Canadian cities.

\section{The New Landscape}

As the thumbnail historical review above suggests, the 1990s were a pivotal decade for federal responses to the reality of Aboriginal urbanization. The period also drew non-governmental organizations into relationships with Aboriginal people and their organizations in the cities. Municipal governments began to be more directly involved as a result of some of these initiatives. For example, in 1996, two important non-governmental organizations, the Federation of Canadian Municipalities (FCM) and the Indian Taxation Advisory Board (ITAB) created the Centre for MunicipalAboriginal Relations. Its mandate was to "promote effective municipalAboriginal relations based on the principles of mutual recognition, respect, sharing and mutual responsibility" by undertaking targeted research and acting as a clearinghouse to develop a database of agreements and effective practices (Aboriginal Council of Winnipeg 1998). RCAP's interest in urban issues played an important role in CMAR's establishment. It was jointly funded by the FCM and the federal government. The mandate of the Centre makes direct reference to the principles advocated by the Royal Commission on Aboriginal Peoples, and while the Centre did not survive as a permanent organization, during its time it worked to address outstanding issues where a reserve was located in or near an urban area. An important CMAR project was the 2001 formation of the Municipal Aboriginal Adjacent Community Cooperation Project. With participation from the FCM, ITAB, and Indian Affairs, this group set out to identify best practices in municipal and First Nations' partnership-building.

In the same spirit of partnership and collaboration, the federal government announced the Urban Aboriginal Strategy (UAS) in 1998. Initially, the UAS was a four-year, \$50-million program to encourage the formation of effective community level organizations to address the socio-economic needs of Aboriginal people in urban centres..$^{18}$ Funding was subsequently renewed in 2003 and again by the Harper Conservative government, in 2007. The UAS is an explicit attempt to develop Aboriginal institutions in cities, and to develop partnerships that will better align federal, other government and non-governmental programs to respond to community priorities, to coordinate federal resources across departments, and to test policy and programming ideas to provide strategic direction. 
Federal attention was drawn to circumstances in Canadian cities, as well. After the restraint measures of the 1990s, city governments faced fiscal shortfalls at the same time as they were experiencing the need to become engaged in supporting economic competitiveness, to replace crumbling public infrastructure, and to deal with immigrant settlement and integration, growing cultural diversity, poverty, and homelessness.

In 1999, the federal government launched its Homelessness Initiative. The main programmatic element of this venture, the Supporting Community Partnerships Initiative (SCPI), reaffirmed and re-enforced the federal government's willingness to now deal with Aboriginal organizations on an important urban issue. Across Canada, designated Aboriginal organizations were funded to provide housing supports for homeless Aboriginal people. Their plans and priorities were to be developed with knowledge of broader community initiatives under SCPI, but they were essentially independent for priority setting, delivery, and accountability, within the terms and conditions of the program. These were set by the federal government.

More generally, Canada's urban challenges were addressed by a Task Force on Urban Issues, led by former Toronto city councillor and federal MP Judy Sgro. The 2002 Task Force Report proposed three priority programs in urban areas: affordable housing, transit/transportation, and sustainable infrastructure. The Task Force had several recommendations specifically related to urban Aboriginal peoples, recommending better coordination of intergovernmental policy delivery; action on poverty, employment, and housing, especially as they relate to urban Aboriginal youth; and sustained support for projects started under the Urban Aboriginal Strategy. The Task Force encouraged co-operation between urban reserves and surrounding areas, attention to Métis and Non-Status urban Aboriginal peoples, and stronger educational supports at the postsecondary level (Sgro 2002, 30$31)$.

Not all of these recommendations were acted upon although, as we have seen, the Urban Aboriginal Strategy has survived both a significant change of government and a global recession. New spending on social programs and on community development ${ }^{19}$ has been eclipsed by the Conservative response to the global recession - a massive infrastructure program. There is no indication of federal interest in tackling outstanding jurisdictional and governance questions, and no sign of an expansive approach to social, education or health spending. Yet, as we shall argue in conclusion, further attention to these matters is necessary. 


\section{Challenges for the Next Decade}

There has never been a comprehensive or coherent policy framework for the federal approach to Aboriginal people living in Canadian cities. Nor has there ever been a full public discussion of urban needs and the realities of Aboriginal life there. Urban Aboriginal issues have appeared on the federal policy agenda episodically, while news coverage tends to focus on problems and dysfunction, even though Canadian cities have seen much in the way of positive changes in relations among Aboriginal residents, their non-Aboriginal neighbours, non-governmental organizations, and city governments. Further, as Newhouse has argued, a rich array of organizations has emerged to support the cultural awareness and community needs of Aboriginal people living in cities (Newhouse 2003).

Federal policy on urban Aboriginal matters has often reflected broader policy preoccupations and programming and collaboration was shaped by the jurisdictional and interdepartmental tensions and contradictions. We have come to a moment in history when a more concerted approach would be helpful. To stimulate thinking in that direction, we offer four "conversation starters," intended to simulate discussion about some key outstanding issues.

1. Is political self-determination less relevant than economic selfdetermination for urban residents?

The 1996 Royal Commission on Aboriginal Peoples focused on the larger issues of the relationship between all Aboriginal peoples and the Crown. The Commission's overall approach emphasized "nation-to-nation" mutuality, on the premise that only this approach, coupled with a frank re-assessment of Canadian history and all of its dark corners, would provide a foundation for a more just and equal future. In this regard, the Commission's report may be seen as the culmination of several decades' political activism, dialogue, litigation, and (ultimately) constitutional change. It is perhaps not the best guide to the future, at least in urban matters.

In line with the nation-to-nation approach, the Commission offered three possible models for institutional development in cities that would respect the principle of Aboriginal self-determination (RCAP 1996). The Commission's final report says relatively little about what is arguably a more important issue for Aboriginal people living in cities: they are 
disproportionately poor, and subject to all of the ills that poverty brings. Should the focus be on urban economic well-being, for the Aboriginal people living in cities and their communities? Rights are clearly central to the well-being and advancement of Aboriginal people but, particularly in the urban context, rights may not, in themselves, be sufficient to bring about the conditions for important changes in the situation of Aboriginal people who live there. This has implications for the federal government. The federal eye must be on responsive public policy related to Aboriginal people in cities, as well as on their rights.

As noted above, the recent period has been characterized by federal investment in Aboriginal urban service delivery organizations. Many of these organizations remain fragile, "punching above their weight" in terms of their contributions to the fabric of urban life. They rely on program or project-based contract funding that provides little or no overhead to engage in policy questions. The Aboriginal SCPI initiative, discussed above, provides a case in point. As argued previously by Walker (2005), policy making related to urban Aboriginal governance and the provision of services will only reconcile rights and needs when it is rooted in co-determination.

2. Progress is hampered by the cities' junior position in the federation. How can this circumstance be ameliorated?

Since the 1990s, cooperation and partnership have been the signature federal policy themes, particularly in relations with Aboriginal people, and certainly in the federal approach to cities and their governments. Arguably, cooperation and partnership are prominent features of the system of federalprovincial-territorial relations through which many large and important decisions are made in Canada. Is there a better way to align both cities, and Aboriginal people living in cities with the federal system? Specifically, more attention needs to be paid to the merits of place-based policy initiatives, such as the federal government's decision to engage in tripartite agreements with provinces and municipalities in Winnipeg and Vancouver, and policies that are more universally applicable. These approaches are not mutually exclusive. The unanswered question is: how can they be used in a complimentary manner to stimulate good results?

3. How can federal policy address the full complexity of urban population dynamics? 
Canadian cities are, increasingly, the home of Aboriginal people from all parts of the country. They are also increasingly home to large populations of new Canadians. Canada's reliance upon immigration to sustain the vitality of the population has had an important effect on the ethnic character of major Canadian cities, and changes to Canadian immigration policy have had a profound impact upon Canadian cities. The major destination cities for new immigrants (Toronto, Vancouver, Montreal), as well as many smaller cities, are now home to adult immigrant populations whose knowledge of the historical basis of Aboriginal rights and governments may be even slighter than that of the population born in Canada. There is probably a special need for education of the general population in Canadian cities about Aboriginal issues, both in the school system and outside of it. Education is, of course, a provincial responsibility, and some provinces are making significant efforts to incorporate education on Aboriginal history and culture into curriculum: Manitoba and Saskatchewan, for example, now teach about treaties. However, we suggest that more needs to be done with youth and the adult population across the country, which implies a federal role. How else may cities be supported to deal with the dynamics of their complex and diverse populations?

Further, there may be a temptation in the public eye and in policy terms to homogenize policy challenges associated with some segments of the urban Aboriginal population and recent immigrants: for example, to be an immigrant is, increasingly, to be poor. Further, arrival in Canada may be accompanied by trauma for refugees and others who have left difficult circumstances (Graham 2007). Practicality suggests that common needs deserve common opportunities and services, but the fundamental relationship of Aboriginal people to the Canadian polity means that federal policy related to the urban Aboriginal population starts from the foundation of Aboriginal rights.

4. Finally, and probably most importantly, what should be done about the legacy of differential programs based upon differentiations among sections of the Aboriginal population that no longer have constitutional salience?

There would seem to be a need here for careful development of a new approach. The Indian Act, and associated jurisdictional problems with it, remain an important difficulty for First Nations members across Canada, but particularly for First Nations people in the city. It is difficult to justify 
differential treatment of First Nations, Métis, and Inuit who live in cities. Some First Nations, and all Métis and Inuit, have never been subject to the Indian Act (though Inuit have received "Indian Act-like" programming under longstanding federal policy). The implementation of the modern treaties mean that there will be Aboriginal people living in Canadian cities who do not have Indian Act status, but who do have responsibilities and benefits as beneficiaries of modern treaties. What are the implications for this for the future federal role? What principles should govern the federal approach? Again, this would seem to speak to issues of rights. In federal policy terms, this speaks to the requirement to recognize rights in an equal manner but sometimes with real approaches that are equitable in recognition of historic and contemporary differences within the urban population.

Part of a long-term solution is, arguably, replacement of the Indian Act with different and less oppressive legislation to give force and form to the federal fiduciary responsibility, to historic and modern treaties, and to the actual relationship embodied in "aboriginal and treaty rights" as these appear in the Canadian constitution. Another part may be something like a "cities charter," or multi-party accord, to facilitate cooperation among the multiple institutional actors and to give guidance to government departments about their respective roles. As we think about the high (perhaps stratospheric) politics of this issue, there may be merit in considering addenda to treaties or to section 35 that address rights and obligations of all parties with regard to the urban population.

For Canadian cities, and for Aboriginal people living in them, the 1990s were a pivotal decade that, in retrospect, contained the seeds of the new circumstances in which we find ourselves. Clearly the future will require careful consideration of these new times, and the imagination and good will to address urban realities in all their unique complexity. We hope that this brief article will be seen as the beginning of the conversation that awaits us all.

\section{Acknowledgments}

We have benefitted from the research assistance of Alyssa Graybeal, Doaa Mahmoud and Evren Tok, as well as from the very helpful comments of the anonymous reviewers, and discussion and papers presented the Congress of the Humanities and Social Sciences colloquium in Montreal on 2 June 2010. 


\section{(Endnotes)}

1. White and Bruhn 2010 provide a good overview of some important changes and current issues. See, in particular, Tomiak in this volume. On Western cities, Hanselmann 2001; 2003. For an analysis that provides context to this discussion, see Green 2005.

2. In this article, for reasons of space and because our primary purpose is to explain certain items that we believe should be on the agenda for public discussion, we do not address the analytical differences among the major authors currently writing about urban Aboriginal affairs. Indeed, we elide the differences, yet these are substantial and interesting. We see, for example, a preoccupation with the link between conceptions of the state (particularly by neo-liberalism) and the discourse and federal agenda related to urban Aboriginal governance (Tomiak 2010); a stream of literature that links definitions of Aboriginal nationhood and citizenship with Aboriginal voices and models of urban service delivery (Anderson and Denis 2003; Walker 2005; 2006); and a focus on the richness and potential of Aboriginal institutions in cities (Newhouse 2003), as well as demographic trends that suggest the need for new models of servicing and governance (Peters 2005; Hanselmann 2001; 2003). We have planned a separate publication to compare approaches and to consider implications for the issues we raise here.

3. The term "Registered Indian" refers to those individuals listed on the Indian Register. As early as the 1850s, colonial officials kept records to identify individual Indians and the Bands to which they belonged, a practice that continued for a hundred years. In 1951, the Indian Register was created, bringing all existing records together.

4. For an extended historical explanation and discussion of impacts in cities, see Peters 2001; Shewell 2004; Malloy 1999.

5. Individuals could give up their Indian registration in order to escape the Indian Act. People did so, for example, in order to be able to vote in federal elections, a right not available to Registered Indians until 1960.

6. Red River Métis became, collectively, almost entirely landless through

a complex historical process. The Red River Resistance prompted the Government of Canada to create the Province of Manitoba in 1870 as a 
homeland for what was then a large majority Métis population. Métis were to retain existing land holdings and were guaranteed a 1.4-million acre land grant for future generations. By 1874, it was clear that the promise inherent in these provisions would not be fulfilled. Amendments to the Manitoba Act authorized the distribution of alienable scrip to individuals, a system that, in turn, led through economic hardship and fraud to the loss of most Métis lands. The ultimately defeated Northwest Resistance of 1885 was fought for the right to be self-governing on collectively held lands. By 1923, when the scrip period ended, approximately 90 percent of Métis lands had been lost to banks and speculators, while the Métis themselves were dispersed across northwestern Canada and south into the United States. A small number of Métis achieved a land base in northern Alberta. See Bell 1999. For an introduction to more contemporary circumstances and issues, see Chartier 1999; for more information concerning cities, see Andersen and Denis 2003.

7. Peters 2001 provides a textured discussion of the crucial 1945-1975 period.

8. Abele and Graham forthcoming.

9. This discussion is focused on the federal role, but it is important to recognize that, during the same period, provincial governments began to develop policy and programs for Aboriginal people (see Hawkes 1989). On the federal approach to urban policy more generally in this period, see Andrew, Graham, and Phillips 2002.

10. Other conflicts in this period included the Peigan protests over the Oldman River Dam in 1990 and the Bear Island/Temagami conflict in 1991. On the significance of these events, see Simpson and Ladner 2010.

11. In the same year, Cabinet established the Indian Claims Commission, an arms-length body charged with reviewing (but not adjudicating) allegations of specific infringements of Treaty rights.

12. It is notable that only the problems facing people in the cities (and rural areas too) are mentioned in this part of the mandate.

13. An early critic of this lacuna in the Royal Commission report was Alan Cairns, who had, at the start of his career, worked on the Hawthorn Commission: see Cairns 2000. For a somewhat different, but similarly critical view, see Andersen and Denis 2003. 
14. See, for example, Gertler and Wolfe 2002; Abele and Papillon 2008. For a discussion of how these changes unfolded in Ontario, where the Harris government introduced even more severe cuts as they restructured social provision, see Marquardt 2007.

15. On the implications of this model for Aboriginal citizenship, see Walker 2006.

16. See Peters 2005 for a discussion of institutional development.

17. The Métis Nation Framework Agreement was signed with the federal government in 2005, and aimed to address this and other longstanding issues, particularly for members of the Métis Nation of Ontario, the Manitoba Métis Federation, the Métis Nation of Saskatchewan, the Métis Nation of Alberta, and the Métis Provincial Council of British Columbia. There is no mention in the Framework Agreement of urban residents, despite the fact that 65 percent of Metis live in cities.

18. Funding was renewed in 2003 and again in 2007, when an additional $\$ 68.5$ million was committed over five years. Walker (2005) presents an important argument about the implications of the UAS style and approach for Aboriginal self-determination. We do not have the space here to consider Walker's analysis, but plan to do so in a subsequent publication.

19. The Martin government's "Communities Agenda" (2004-2005) had barely launched when the government was defeated.

\section{References}

Abele, Frances. 2000. "STmall Nations and Democracy’s Prospects: Indigenous People in Canada, Australia, New Zealand, Norway and Greenland." Inroads: A Journal of Opinion 10: 137-49.

- - - 2004. Urgent Need: Serious Opportunity: Towards a New Social Model for Canada's Aboriginal Peoples. Ottawa: CPRN.

- - - 2007. Like An Ill-Fitting Boot: Government, Governance and Management Systems in the Contemporary Indian Act. Vancouver and Ottawa: National Centre for First Nations Governance. 
Abele, Frances, and Katherine A. H. Graham. 1988. "Plus Que Ca Change . . . Northern and Native Policy." In How Ottawa Spends 1988-89, ed. Katherine A. H. Graham, 113-38. Ottawa: Carleton University Press.

Abele, Frances and Katherine A. H. Graham. Forthcoming. "Federal Urban Aboriginal Policy: The Challenge of Viewing the Stars in the Urban Night Sky." In Urban Aboriginal Policy Making in Canadian Municipalities, ed. Evelyn Peters. Montreal and Kingston: McGillQueen's University Press.

Aboriginal Council of Winnipeg, Institute on Governance, and Centre for Municipal-Aboriginal Relations. 1998. Aboriginal Governance in Urban Setting: Completing the Circle Conference Summary and Conclusions. Winnipeg.

Andersen, Chris, and Claude Denis. 2003. "Urban Natives and the Nation: Before and After the Royal Commission on Aboriginal Peoples." Canadian Review of Sociology 40 (4): 373-90.

Andrew, Caroline, Katherine A. H. Graham, and Susan D. Phillips, eds. 2002. Urban Affairs: Back on the Policy Agenda? Kingston and Montreal: McGill-Queen's University Press.

Barron, F. Laurie. 1984. "A Summary of Federal Indian Policy in the Canadian West, 1867-1984." Native Studies Review 1: 28-39.

Bell, Catherine. 1999. "Metis Self-Government: The Alberta Settlement Model." In Aboriginal Self-Government in Canada, ed. John H. Hylton, 329-50. Saskatoon, SK: Purich.

Cairns, Alan C. 2000. Citizens Plus: Aboriginal Peoples and the Canadian State. Vancouver: UBC Press.

Canada. Minister of Indian Affairs and Northern Development. 1995. The Government of Canada's Approach to Implementation of the Inherent 
Right and the Negotiation of Aboriginal Self-Government. http://www.ainc-inac.gc.ca/al/ldc/ccl/pubs/sg/sg-eng.asp\#PartI.

Canada. DIAND [Department of Indian Affairs and Northern Development] and Office of the Federal Interlocutor. 1998. Gathering Strength: Canada's Aboriginal Action Plan. Ottawa: Minister of Public Works and Government Services Canada.

Canada. Statistics Canada. 2003. Aboriginal Peoples of Canada: A Demographic Profile. 2001 Census: Analysis Series. Ottawa: Ministry of Industry.

Chartier, Clem. 1999. "Aboriginal Self-Government and the Metis Nation." I. Aboriginal Self-Government in Canada, ed. John H. Hylton. Saskatoon, SK: Purich: 112-28.

Gertler, Meric S and David Wolfe, eds. 2002. Innovation and Social Learning: Institutional Adaptation in an Era of Technological Change. New York: Palgrave Macmillan.

Graham, Katherine A. 2007. Our Diverse Cities: Ontario. Ottawa: Metropolis.

Graham, Katherine A. and Susan Phillips. 2007. "Another Fine Balance: Managing Diversity in Canadian Cities." In The Art of the State III: Belonging? Diversity, Recognition and Shared Citizenship in Canada, ed. Keith Banting, Thomas Courchene, and Leslie Seidle, 155-94. Montreal: IRPP.

Green, Joyce. 2005. "Self-Determination, Citizenship and Federalism: Indigenous and Canadian Palimpsest." In Canada: The State of the Federation: Reconfiguring Aboriginal State Relations, ed. Michael Murphy. Montreal and Kingston: McGill-Queen's University Press.

Hanselmann, Calvin. 2001. Urban Aboriginal People in Western Canada: Realities and Policies. Calgary: Canada West Foundation. 
- - - 2003. Shared Responsibilities: Final Report and Recommendations of the Urban Aboriginal Initiative . Calgary: Canada West Foundation.

Hawkes,David.1989.AboriginalPeoples and Government Responsibilities: Exploring Federal and Provincial Roles. Ottawa: Carleton University Press.

Hawthorn, H. B. 1966-67. A Survey of the Contemporary Indians of Canada: Economic, Poitical and Educational Needs and Policies, 2 vols. Ottawa: Indian and Northern Affairs Canada.

Larbi, Patrick. 1998. A Portrait of Municipal-Aboriginal Relations in Canada. Prepared for CMAR [Ottawa Centre for MunicipalAboriginal Relations].

Loxley, John and Fred Wein. 2003. Urban Aboriginal People: History of Discriminatory Laws. Ottawa: Depository Services Program, Law and Government Division.

Marquardt, Richard. 2007. The Progressive Potential of Municipal Social Policy: A Case Study of the Struggle over Welfare Reform in Ottawa during the Common Sense Revolution. PhD dissertation, Carleton University.

Newhouse, David. 2003. "The Invisible Infrastructure: Urban Aboriginal Institutions and Organizations." In Not Strangers in These Parts: Urban Aboriginal Peoples, ed. David Newhouse and Evelyn Peters, 243-54. Ottawa: Policy Research Initiative:.

Peters, Evelyn J. 2001. "Developing Federal Policy for First Nations People in Urban Areas: 1945-1975." The Canadian Journal of Native Studies 21 (1): 57-96.

- - . 2005. "Progress in Planning: Indigeneity and Marginalization." Planning for and with Urban Aboriginal Communities in Canada 63 (4): 325-404. 
Peters, Evelyn. 2007. "First Nations and Metis People and Diversity in Canadian Cities." In Diversity, Recognition and Shared Citizenship in Canada, eds. Keith Banting, Thomas J. Courchene and F. Leslie Seidle. Montreal: Institute for Research on Public Policy.

Peach, Ian. 2004. The Death of Deference: National Policy Making in the Aftermath of Meech Lake and Charlottetown Accords. Regina: Saskatchewan Institute of Public Policy.

Ponting, J.R. and R. Gibbons. 1980. Out of Irrelevance: A Sociopolitical Introduction to Indian Affairs in Canada. Toronto: Butterworthy.

Sgro, Judy. 2002. Canada's Urban Strategy: A Blueprint for Action [Sgro Report]. Ottawa: Prime Minister's Caucus Task Force on Urban Issues.

Shewell, Hugh. 2004. "Enough to Keep Them Alive”: Indian Welfare in Canada, 1873-1965. Toronto: University of Toronto Press.

Simpson, Leanne and Kiera Ladner. 2010. This Is An Honour Song: Twenty Years Since the Blockades. Winnipeg: Arbeiter Ring.

Tamera Services Limited. 2002. Report Governing Relations Between Local Government and First Nation Government. www.cd.gov. bc.ca/lgd/gov_structure/library/first_nations_report.pdf.

Tomiak, Julie. 2010. "Indigenous Governance in Winnipeg and Ottawa: Making Space for Self-Determination.” In Aboriginal Policy Research: Exploring the Urban Landscape, ed. Jerry P. White and Jody Bruhn. Toronto: Thompson Educational Publishing.

Walker, Ryan. 2005. "Social Cohesion? A Critical Review of the Urban Aboriginal Strategy and Its Application to Address Homelessness in Winnipeg." Canadian Journal of Native Studies 25 (2): 395-416.

- - - . 2006. "Interweaving Aboriginal/Indigenous Rights with Urban Citizenship: A View from the Winnipeg Low-Cost Housing Sector." Citizenship Studies 10 (4): 391-411. 
White, Jerry P. and Jody Bruhn, eds. 2010. Aboriginal Policy Research:

Exploring the Urban Landscape. Toronto: Thompson Educational Publishing.

Wherrett, Jill. 1999. Federal Policy Guide: Aboriginal Self-Government. Ottawa: Library of Parliament, Political and Social Affairs Division. 